\title{
Employer Satisfaction with Polytechnic Graduate: Comparison Between Industry Cluster
}

\author{
Husnira binti Hussin \\ Department of Mathematics, Science and Computer, \\ Politeknik Sultan Mizan Zainal Abidin \\ $\mathrm{Km}$ 08, Jalan Paka, \\ 23000 Dungun, Terengganu \\ husnira@psmza.edu.my \\ Rusdi bin Rusli \\ Department of Civil Engineering, \\ Politeknik Sultan Mizan Zainal Abidin \\ $\mathrm{Km}$ 08, Jalan Paka, \\ 23000 Dungun, Terengganu \\ diri65@yahoo.com \\ Wan Mohd Zawawi bin Wan Yunus \\ Department of Mathematics, Science and Computer, \\ Politeknik Sultan Mizan Zainal Abidin \\ Km 08, Jalan Paka, \\ 23000 Dungun, Terengganu \\ wan.zawawi@psmza.edu.my
}

\begin{abstract}
The work environment is changing from time to time in line with the introduction of new technology. Industrial Revolution 4.0 (IR4.0) forces education providers to identify the characteristics of future workers' needs by the industry. To fulfill this demand, polytechnic created a close relationship with industry through conducting many programs such as dialog between industry and polytechnic, CEO@Faculty, the industry in campus and employer satisfaction study with polytechnic graduate. However, previous studies compared employer satisfaction among industry clusters are very limited. The objective of this study was to examine employer satisfaction with Politeknik Sultan Mizan Zainal Abidin (PSMZA) graduate and to compare employer satisfaction between industry clusters. A total of 112 employers from three main engineering clusters; mechanical (46\%), electrical (30\%) and civil (24\%) involved in this study. This study used two-step analysis: Kruskal-Wallis test was used to identify differences for three industry clusters; mechanical, electrical and civil engineering and Post Hoc test performs to identify the detail differences between each cluster. The results show that employers in the mechanical engineering cluster are less satisfied with PSMZA graduates compared to employers in civil engineering clusters for computer skills in processing information. This study also found that compared to employers in the electrical engineering cluster, employers in the mechanical cluster are less satisfied with PSMZA graduates related to proficiency in the English language. In terms of entrepreneurship skills, employers in the mechanical cluster found less satisfaction with a graduate from PSMZA compared to employers in the electrical cluster. Findings from this study can be used by the department as a guide in revising their curriculum in the future.
\end{abstract}

Key Words: employer satisfaction, polytechnic graduate, industry cluster 


\section{INTRODUCTION}

The two biggest concerns of employers today are to identify and train good workers. Although employers would prefer to recruit people who are trained and ready to go to work, they are usually able to provide the advanced, job specific training required for those who lack these skills. The gap between what students learn in institutions of higher education and what they need to know and should be able to do in the workplace is a long-standing issue. To be competitive, Malaysia should have a market driven education system that can produce students who are ready for work.

Looking for workers who have employability or job preparations skills that help them in shape into and remain in the work sorroundings is a actual problem. Employers need responsible workers who can solve problems and who have the social skills and attitudes to work with other workers. A joint report by Chavez, Camello, Angelie \& Pamplona (2016) noted that employers strongly preferred employees, who are loyal and committed to their works and functions; responsible team members; with strong moral values and high sense of professionalism.

\section{Literature review}

Kubler and Forbes (2004) describes engineering to be the occupation aimed at qualified practice, through training and professional education in a specific engineering discipline, of a distinctive knowledge based on mathematics, science and technology, incorporated into business and management. Zaharim, Yusoff, Omar, Mohamed, Muhamad and Mustapha (2009) define engineering as the growth, distribution, and management of industry and community infrastructures, goods and services. In other meaning, engineering therefore means someone with certain skills to effectively apply and practice knowledge on the job.

From the point of view of researcher, engineering offers the ability to learn a profound scientific skill, to use a method in the architecture, service and application of technology such as computer systems, equipment, software and engineering instruments. The ability to learn, learn new engineering skills and to be improved is also part of the changing technological change. Thus, industries require all new workers to have certain skills to succeed in their work and careers (Yusoff, Omar, Zaharim, Mohamed \& Muhamad, 2012). In other meaning, today employers seek out not only good workers with fundamental academic skills such as reading, writing, listening and oral, communication skills and basic scientific and mathematical knowledge, but also employees who have more intellectual knowledge, including the knowledge of creativity, teaching, reasoning and decision-making (Shafie \& Nayan, 2010). 
In Malaysia, employers complained of graduate candidates who lack traditional skills but satisfied with engineering graduates' professional skills and technological competence (Johari, Zaini, Zaharim, Basri \& Omar, 2011). In addition, Hassan, Zaidi, Zainal, Abdullah, Badrulhisham, Hamid and Zaidi (2007) claim that engineering programs in all fields, in particular in non-technical areas are desperately necessary to improve. Thus, thirteen most relevant basic skills learned in engineering by students were defined in the employability skills system developed by Hassan et al., (2007). The competences of Requirements for Accrediting Engineering Program are determined by requirements of technical competence. Table 1.1 sums up the conclusions regarding engineering skills in terms of the value of the employer-related skills.

Table 1. Engineering Graduate Skills (Hassan et al., 2007)

\begin{tabular}{|c|c|}
\hline Skills & \\
\hline Communication effectively & $\begin{array}{l}\text { te ideas in aural, oral and written } \\
\text { eers but with the society as a whole, }\end{array}$ \\
\hline $\begin{array}{l}\text { Competent in application and } \\
\text { practice }\end{array}$ & odern engineering tools, technique and \\
\hline $\begin{array}{l}\text { Interpersonal or team working } \\
\text { skills }\end{array}$ & $\begin{array}{l}\text { ability of a person and a company with the ability to be a } \\
\text { er or boss as well as an effective team member }\end{array}$ \\
\hline $\begin{array}{l}\text { Engineering problem solving and } \\
\text { decision making skills }\end{array}$ & oblems, devise \\
\hline $\begin{array}{l}\text { dge of science and } \\
\text { rinciples }\end{array}$ & ply engineering knowledge \\
\hline pecific engineering & ular \\
\hline $\begin{array}{l}\text { Understand professional, social } \\
\text { and } \\
\text { ethical responsibilities }\end{array}$ & $\begin{array}{l}\text { er's financial, } \\
\text { nsibility and a }\end{array}$ \\
\hline Life & the potential to pursue \\
\hline Engir & $\begin{array}{l}\text { a program approach to design and } \\
\text { ssment }\end{array}$ \\
\hline Desi & $\begin{array}{l}\text { nd execute experiments and the study and } \\
\text { a. }\end{array}$ \\
\hline $\begin{array}{l}\text { Knowledge of co } \\
\text { issues }\end{array}$ & $\begin{array}{l}\text { ity to develop new ideas, } \\
\text { y. }\end{array}$ \\
\hline Competency in theoretical and & $\begin{array}{l}\text { Having the competency in theoretical and research } \\
\text { engineering. }\end{array}$ \\
\hline I & 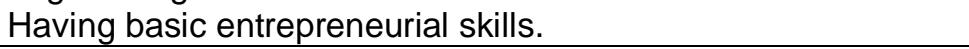 \\
\hline
\end{tabular}

\section{Problem statement}

The need for expertise by the manufacturing sector must fit with the nature of the demands of the business and the ability to promote the engineer's profession as suggested by Rasul, Rauf, Mansor, Yasin and Mahamod (2013). Moreover, employer finding workers who could adapt to change, in particular in terms of services, product, process and has been the employer's meta-characteristic requirement (Grip, Loo \& Sanders, 2004) Saleh (2019) also states that recently come up with a challenge to the market for employability, which appears to be difficult to sustain both sides as technical and ongoing developments, are rapidly expanding. Thus, knowledge is critical for 
adapting workers to changes and enhancing workforce capacity.

Employers need an accurate indicator for engineer recruitment purposes (Jackson, 2010). This is because engineers who have the expertise but do not meet market demand and needs are not being hired because they are not suited to the need for skills. The implications of this scenario are many engineers are jobless and cannot be employed because the graduates lack the necessary qualifications. In order to stop this, multiple experiments were carried out in order to identify the reasons behind this increment and to solve this problem. One problem is that graduates lack the skills required for their employability (Zaharim, Yusoff, Omar, Mohamed, Muhamad \& Mustapha, 2009). This may be true as Saad and Majid (2014) states that employers are still not happy with graduate skills.

Based on the current information of unemployment rate in Malaysia, in the second quarter of 2019, the Statistics Department reported 516,600 unemployed people in Malaysia (Department of Statistics Malaysia, 2020). This figure is somewhat alarming as it can trigger difficulties for graduates who seeking for the job. This is because graduate unemployment has been a concern over Malaysia (Cheong, Hill, Fernandez-Chung \& Leong, 2016). Although universities have been called on to work closer with businesses to ensure compliance with skills and jobs, it continues to be a problem. Therefore, the aim of this study is to examine the factor affecting employer's satisfaction among industry cluster with Politeknik Sultan Mizan Zainal Abidin (PSMZA) graduate. It is hoped that this research will provide engineering students with the relevant information to increase awareness of the capabilities of employability and their planning to enter the workforce. Hopefully the findings will help students improve their personal skills before they graduate and go for a job interview.

\section{Research Objectives}

This study was conducted to compare the employer satisfaction with PSMZA graduate based on engineering discipline.

\section{RESEARCH METHOD}

A set of questionnaires were distributed through online system in Google form to the company which has registered as an employer for PSMZA graduate. As alternative, this questionnaire also posted to address register by student during convocation. This study used two-step analysis: Kruskal-Wallis test was used to identify differences for three industry cluster; mechanical, electrical and civil engineering. Post Hoc test performs to identify the detail differences between each cluster.

\section{Results}

\section{RESULTS AND DISCUSSION}

This study was conducted to examine the satisfaction of employer with graduate from PSMZA. A total of 112 companies from three main engineering field contributed in this study where 52 from mechanical, 33 from electrical and 27 from civil engineering. Analysis was separated to four categories which are graduate skills, knowledge, soft skills and employer satisfactions as illustrated in Table 2, Table 3, Table 4 and Table 5.

Table 2 shows results of graduate skills by different cluster. From seven items included in this category, using computer in processing information is found to be 
statistically significant between clusters.

Table 1. Engineering Graduate Skills (Hassan et al., 2007)

\begin{tabular}{|c|c|c|c|c|c|}
\hline Variables & Cluster & $\mathbf{N}$ & $\begin{array}{l}\text { Mean } \\
\text { Rank }\end{array}$ & $\chi^{2}$ & $\begin{array}{c}p- \\
\text { value }\end{array}$ \\
\hline \multirow{3}{*}{ Information management skill } & Mechanical & 52 & 50.04 & & \\
\hline & Electrical & 33 & 64.89 & 4.996 & 0.082 \\
\hline & Civil & 27 & 58.69 & & \\
\hline \multirow{3}{*}{$\begin{array}{l}\text { Using computer in processing } \\
\text { information }\end{array}$} & Mechanical & 52 & 46.65 & & \\
\hline & Electrical & 33 & 61.83 & $11.285^{\star}$ & 0.004 \\
\hline & Civil & 27 & 68.94 & & \\
\hline \multirow{3}{*}{ Skill in choosing tools/technology } & Mechanical & 52 & 51.48 & & \\
\hline & Electrical & 33 & 61.02 & 2.355 & 0.308 \\
\hline & Civil & 27 & 58.76 & & \\
\hline \multirow{3}{*}{ Skill in innovative thinking } & Mechanical & 52 & 52.85 & & \\
\hline & Electrical & 33 & 62.32 & 2.098 & 0.350 \\
\hline & Civil & 27 & 56.43 & & \\
\hline \multirow{3}{*}{ Skill in creative thinking } & Mechanical & 52 & 54.20 & & \\
\hline & Electrical & 33 & 62.41 & 1.866 & 0.393 \\
\hline & Civil & 27 & 53.70 & & \\
\hline \multirow{3}{*}{ Skill in decision making } & Mechanical & 52 & 57.13 & & \\
\hline & Electrical & 33 & 62.80 & 3.758 & 0.153 \\
\hline & Civil & 27 & 47.59 & & \\
\hline \multirow{3}{*}{ Skill in problem solving } & Mechanical & 52 & 56.63 & & \\
\hline & Electrical & 33 & 62.62 & 3.081 & 0.214 \\
\hline & Civil & 27 & 48.76 & & \\
\hline
\end{tabular}

*significant at the 0.5 level 
Table 3 shows results of graduate knowledge by different cluster. From four items included in this category, none of the variables are found to be statistically significant between clusters.

Table 2. Graduate Knowledge between Cluster

\begin{tabular}{lccccc}
\hline Variables & Cluster & N & $\begin{array}{c}\text { Mean } \\
\text { Rank }\end{array}$ & $\chi^{2}$ & $\begin{array}{c}\boldsymbol{p} \text { - } \\
\text { value }\end{array}$ \\
\hline \multirow{3}{*}{ Knowledge on technology application } & Mechanical & 52 & 55.74 & & \\
& Electrical & 33 & 59.29 & 0.430 & 0.807 \\
& Civil & 27 & 54.56 & & \\
Knowledge on technology application & Electrical & 33 & 58.36 & 0.477 & 0.788 \\
& Civil & 27 & 58.30 & & \\
Knowledge on information management & 52 & 54.38 & & \\
& Eechanical & 52 & 54.06 & & \\
& Electrical & 33 & 61.92 & 1.503 & 0.472 \\
& Civil & 27 & 54.57 & & \\
Knowledge on job scope & Mechanical & 52 & 53.15 & & \\
& Electrical & 33 & 60.29 & 1.261 & 0.532 \\
& Civil & 27 & 58.31 & & \\
\hline
\end{tabular}

*significant at the 0.5 level

Table 4 shows results of graduate soft skills by different cluster. From seven items included in this category, proficient in English language and entrepreneurship skills are found to be statistically significant between clusters.

Table 3. Graduate Soft Skills between Cluster

\begin{tabular}{lccccc}
\hline \multicolumn{1}{c}{ Variables } & Cluster & N & $\begin{array}{c}\text { Mean } \\
\text { Rank }\end{array}$ & $\chi^{\mathbf{2}}$ & $\begin{array}{c}\boldsymbol{p} \text { - } \\
\text { value }\end{array}$ \\
\hline \multirow{2}{*}{ Discipline in work task } & Mechanical & 52 & 55.02 & & \\
& Electrical & 33 & 63.02 & 2.484 & 0.289 \\
& Civil & 27 & 51.39 & & \\
Good communication skills & Mechanical & 52 & 55.50 & & \\
& Electrical & 33 & 57.02 & 0.123 & 0.940 \\
Able to work in a team & Civil & 27 & 57.80 & & \\
\hline
\end{tabular}




\begin{tabular}{lcccccc}
\hline & Electrical & 33 & 59.48 & & \\
& Civil & 27 & 58.44 & & \\
Mechanical & 52 & 53.49 & & \\
Proficient in English Languag e & Electrical & 33 & 68.33 & $7.707^{*}$ & 0.021 \\
& Civil & 27 & 47.83 & & \\
Mechanical & 52 & 56.69 & & \\
Mriculous in task given & Electrical & 33 & 59.14 & 0.641 & 0.726 \\
& Civil & 27 & 52.91 & & \\
Mechanical & 52 & 52.02 & & \\
& Electrical & 33 & 63.52 & 3.032 & 0.220 \\
& Civil & 27 & 56.56 & & \\
Entrepreneurship skills & Mechanical & 52 & 51.05 & & \\
& Electrical & 33 & 67.11 & $5.762^{*}$ & 0.046 \\
& Civil & 27 & 54.04 & & \\
\hline
\end{tabular}

*significant at the 0.5 level

Table 5 shows results of employer satisfaction between cluster. From eight items included in this category, none of the variables are found to be statistically significant between clusters.

Table 4. Employer Satisfaction between Cluster

\begin{tabular}{|c|c|c|c|c|c|}
\hline Variables & Cluster & $\mathbf{N}$ & $\begin{array}{l}\text { Mean } \\
\text { Rank }\end{array}$ & $x^{2}$ & $\begin{array}{c}p- \\
\text { value }\end{array}$ \\
\hline & Mechanical & 52 & 56.98 & & \\
\hline \multirow[t]{3}{*}{ Work readiness } & Electrical & 33 & 56.06 & 0.027 & 0.987 \\
\hline & Civil & 27 & 56.11 & & \\
\hline & Mechanical & 52 & 53.54 & & \\
\hline \multirow[t]{3}{*}{ Ability to adapt work situation } & Electrical & 33 & 57.27 & 1.220 & 0.543 \\
\hline & Civil & 27 & 61.26 & & \\
\hline & Mechanical & 52 & 57.12 & & \\
\hline \multirow[t]{3}{*}{ Fast action in performing task } & Electrical & 33 & 58.38 & 0.524 & 0.769 \\
\hline & Civil & 27 & 53.02 & & \\
\hline & Mechanical & 52 & 55.27 & & \\
\hline \multirow[t]{2}{*}{ Shows a good work performance } & Electrical & 33 & 58.00 & 0.185 & 0.912 \\
\hline & Civil & 27 & 57.04 & & \\
\hline Ability to prioritize the work & Mechanical & 52 & 53.22 & 1.483 & 0.476 \\
\hline
\end{tabular}




\begin{tabular}{lccccc} 
& Electrical & 33 & 57.23 & & \\
& Civil & 27 & 61.93 & & \\
Mechanical & 52 & 55.21 & & \\
Dependability & Electrical & 33 & 55.70 & 0.475 & 0.789 \\
& Civil & 27 & 59.96 & & \\
Mechanical & 52 & 58.07 & & \\
Practice good work & Electrical & 33 & 57.08 & 0.584 & 0.747 \\
& Civil & 27 & 52.78 & & \\
Willingness to work hard & Mechanical & 52 & 54.26 & & \\
& Electrical & 33 & 59.45 & 0.652 & 0.722 \\
\hline
\end{tabular}

*significant at the 0.5 level

Table 6 shows a Kruskal-Wallis test which reveal that there was a statistically significant difference $(P<0.05)$ in variables between the different clusters. The results show that employers in mechanical engineering cluster are less satisfied with PSMZA graduate compared to employers in civil engineering cluster for computer skill in processing information. This study also found that compared to employers in electrical engineering cluster, employers in mechanical cluster are less satisfaction with PSMZA graduate related to proficient in English language. In term of entrepreneurship skill, employers in mechanical cluster found less satisfaction with graduate from PSMZA compared to employers in electrical cluster.

Table 5. Comparison on Significant Variables

\begin{tabular}{|c|c|c|c|c|c|}
\hline $\begin{array}{c}\text { Dependent } \\
\text { Variable }\end{array}$ & $\begin{array}{l}\text { Cluster } \\
\text { (I) }\end{array}$ & $\begin{array}{c}\text { Cluster } \\
\text { (J) }\end{array}$ & $\begin{array}{c}\text { Mean Difference } \\
(\mathrm{I}-\mathrm{J})\end{array}$ & $\begin{array}{l}\text { Std. } \\
\text { Error }\end{array}$ & Sig. \\
\hline \multirow{3}{*}{$\begin{array}{l}\text { Using computer in } \\
\text { processing } \\
\text { information }\end{array}$} & \multirow{2}{*}{ Mechanical } & Electrical & -0.341 & 0.192 & 0.223 \\
\hline & & Civil & $-0.546^{\star}$ & 0.171 & 0.007 \\
\hline & Electrical & Civil & -0.205 & 0.216 & 0.716 \\
\hline \multirow{3}{*}{$\begin{array}{l}\text { Proficient in English } \\
\text { Language }\end{array}$} & \multirow{2}{*}{ Mechanical } & Electrical & $-0.436^{\star}$ & 0.187 & 0.047 \\
\hline & & Civil & 0.146 & 0.218 & 0.876 \\
\hline & Electrical & Civil & $0.582^{*}$ & 0.246 & 0.043 \\
\hline \multirow{3}{*}{$\begin{array}{l}\text { Entrepreneurship } \\
\text { skills }\end{array}$} & \multirow{2}{*}{ Mechanical } & Electrical & $-0.437^{\star}$ & 0.195 & 0.050 \\
\hline & & Civil & -0.050 & 0.222 & 0.994 \\
\hline & Electrical & Civil & 0.387 & 0.249 & 0.327 \\
\hline
\end{tabular}

*significant at the 0.5 level 


\section{Discussion}

With respect to the first research objectives, the results indicate that there are three factors that influence the employer's satisfaction of the capabilities of the engineering graduate's that have arisen from this analysis. From the result above, researcher can concluded that a Kruskal-Wallis test showed that there was a statistically significant difference $(\mathrm{P}<0.05)$ of using computer in processing information variables between the different cluster with a mean rank score of 46.65 for mechanical, 61.83 for electrical and 68.94 for civil. Besides that, a statistically significant difference $(P<0.05)$ has been found on proficient in English language between the different cluster with a mean rank score of 53.49 for mechanical, 68.33 for electrical and 47.83 for civil. Lastly, the test also shows a statistically significant difference $(P<0.05)$ of entrepreneurship skills between the different cluster with a mean rank score of 51.05 for mechanical, 67.11 for electrical and 54.04 for civil. This study should be able to demonstrate the value of a wide range of skills and abilities for industrial employers in the pursuit and retention of their workers.

\section{CONCLUSION}

The study's main contribution was to validate the employer satisfaction assessment of skills of engineering graduates that impact the skills required in engineering fields with a focus on Malaysia. Subsequently, the factors that become important to graduate employability skills were identified as fundamental general skills and engineering skills. It also has the competences that employers need to satisfy the rising demand for higher skills in the area of technology to fulfill the need for higher skills in order to succeed in the current competitive economic industry.

\section{REFERENCES}

Chavez, N. H., Camello, N. C., Angelie, M., \& Pamplona, I. (2016). Employability of Engineering Graduates from 2013 to 2015: Basis for a Proposed Student Development Program. Asia Pacific Journal of Education, Arts and Sciences, 3(34), 27-39. Retrieved from www.apjeas.apjmr.com

Cheong, K. C., Hill, C., Fernandez-Chung, R., \& Leong, Y. C. (2016). Employing the 'unemployable': employer perceptions of Malaysian graduates. Studies in Higher Education, 41(12), 2253-2270.

Grip, A. D, Loo, J. V., \& Sanders, J. (2004). The industry employability index: Taking account of supply and demand characteristics. Int'l Lab. Rev., 143, 211.

Department of Statistics Malaysia. (2020). Labour Force \& Social Statistics. Retrieved February 6, 2020, from https://www.dosm.gov.my/v1/index.php?r=column/ cthemeByCat\&cat=149\&bul id=ekx5ZDVkVFAyWGg3WHNLUnJWL3RwUT0 9\&menu id=U3VPMldoYUxzVzFaYmNkWXZteGduZz09

Hassan, B., Zaidi, M. O., Zainal, M., Abdullah, M. A., Badrulhisham, A. A., Hamid, A. A., ... \& Zaidi, M. R. (2007). The future of engineering education in 
Malaysia. report by the Department if Institutions of Higher Education Management, Ministry of Higher Education, Malaysia.

Jackson, D. (2010). An international profile of industry-relevant competencies and skill gaps in modern graduates. International Journal of Management Education, 8(3), 29-58.

Johari, M. H., Zaini, R. M., Zaharim, A., Basri, H., \& Omar, M. Z. (2011). Perception and expectation toward engineering graduates by employers: A UKM study case. In 2011 3rd International Congress on Engineering Education (ICEED) (pp. 203-207). IEEE.

Kubler, B., \& Forbes, P. (2004). Student employability profiles engineering. Enhancing Student Employability Coordination Team (ESECT).

Rasul, M. S., Rauf, R. A. A., Mansor, A. N., Yasin, R. M., \& Mahamod, Z. (2013). Graduate employability for manufacturing industry. Procedia-Social and Behavioral Sciences, 102, 242-250.

Saad, M. S. M., \& Majid, I. A. (2014). Employers' perceptions of important employability skills required from Malaysian engineering and information and communication technology (ICT) graduates. Global Journal of Engineering Education, 16(3), 110-115.

Saleh, H. (2019). Employer Satisfaction With Engineering Graduates Employability: A Study Among Manufacturing Employers In Malaysia. International Journal of Scientific \& Technology Research, 8(9), 819-817.

Shafie, L. A., \& Nayan, S. (2010). Employability awareness among Malaysian undergraduates. International Journal of Business and Management, 5(8), 119.

Yusoff, Y. M., Omar, M. Z., Zaharim, A., Mohamed, A., \& Muhamad, N. (2012). Employability skills performance score for fresh engineering graduates in Malaysian industry. Asian Social Science, 8(16), 140.

Zaharim, A., Yusoff, Y. M., Omar, M. Z., Mohamed, A., Muhamad, N., \& Mustapha, R. (2009). Employers perception towards engineering employability skills in 